\title{
Kèjhungan: Gaya Nyanyian Madura dalam Pemaknaan Masyarakat Madura Barat pada Penyelenggaraan Tradisi Rèmoh
}

\author{
Zulkarnain Mistortoify ${ }^{1}$, Timbul Haryono, Lono L. Simatupang, dan Victorius Ganap \\ Program Studi Pengkajian Seni Pertunjukan dan Seni Rupa, Sekolah Pascasarjana, \\ Universitas Gadjah Mada Yogyakarta
}

\begin{abstract}
Kèjhungan in Rèmoh Tradition on West Madura. Kèjhungan or singing style comes from the activity of people singing about their everyday lives in Madura's society. When the kèjhungan has become an "established" singing style, therefore the meaning of the kejhungan includes the ownership meaning that is inherited through oral traditions and legitimized in the culture of the people of Madura. The research's assumption explains that the existence of the kèjhungan becomes an important conscious for the whole singing culture of the Madura people. Even, in the elite village life for example in the "gathering tradtion" of blatèr community, kèjhungan has become their identity of existence. This research is a study on the representation of values when the kèjhungan is made as a symbol or legitimate image for the blater community in the Madura society. The findings of this research explains that kejhungan has become the object of consumption that is advanced to the blater community in achieving their respect. With their power, the blater can construct traditional kèjhungan values into outstanding symbols in strengthening their existence in Madura's society.
\end{abstract}

Key words: blatèr community - meaning - kèjhungan - rèmoh tradition.

\section{Pendahuluan}

Kata kèjhungan, berasal dari kata kejhung atau nyanyian. Skala pengertian umum, kèjhungan mencakup makna kepemilikan sebagai gaya nyanyian rakyat yang diwariskan secara tradisi lisan di Madura. Kejhungan memiliki cengkok nyanyian yang khas, disertai dengan cara-cara pengungkapan tertentu yang mencerminkan perasaan dan estetika kolektif masyarakatnya. Praktik ekspresinya begitu kuat, bahkan menjadi ciri dari kèjhungan ini. Ekspresi dengan greget yang menonjol seringkali membuat orang awam menilai kejhungan bukanlah nyanyian yang "wajar", tetapi lebih dikesankan seperti orang yang sedang berkeluh kesah, meratap, dan dilantunkan dengan nyaring (setengah berteriak) atau diistilahkan ong-klaongan.

Turner menulis bahwa ekspresi merupakan pengungkapan kristalisasi dari suatu pengalaman hidup manusia. Menurut Bruner, ekspresi selalu mempunyai hubungan dengan pengalaman budaya masyarakatnya. Hubungannya begitu dialogis dan dialektis ketika "pengalaman menstrukturekspresi”, namun sebaliknya "ekspresi juga menstruktur pengalaman" (misalnya melalui ekspresi gaya nyanyian), dan di situlah ekspresi pada batas tertentu mampu menerangkan pengalaman terdalam manusia. Dari kedua hubungan pengalaman dan ekspresi itu, pemaknaan indigenous dapat ditemukan, sebab ekspresi tersebut merupakan artikulasi, formulasi, dan representasi dari pengalaman mereka sendiri (Bruner and Turner, 1986: 5,6,9).

Praktik kèjhungan (ngèjhung) yang sifatnya spontan dan situasional dalam keseharian secara gamblang seringkali diekspresikan manakala dalam suasana hati yang emosional, seperti ketika dalam suasana sedih, kesal, putus asa, marah, bangga, gembira, ataupun sekadar mengusir rasa sepi atau bosan. Dalam banyak kasus, momentum ngèjhung itu dapat terjadi ketika seseorang sedang kesal namun tidak mampu berbuat apaapa; atau ketika seseorang baru saja kehilangan anggota keluarga yang dicintainya, maka ia akan mengekspresikan kedukaannya yang mendalam itu hingga ratapannya seperti "menyanyi" (ekspresi kedukaannya bermuatan melodis).

Kejhungan dalam pengertian sajian formal merupakan kegiatan (praktik) menyanyi yang mengacu pada suatu gending. Kejhungan dalam pengertian yang formal inilah yang menjadi objek material penelitian ini. Alasannya, kèjhungan

1 Alamat korespodensi: Jln. Ki Hajar Dewantara 19, Kentingan, Surakarta, 57126, Telp. (0271) 647658. HP: 081329224066.

E-mail: mistortoify@yahoo.com 
pada konteks ini cenderung disajikan dalam perulangan pola gaya nyanyian yang relatif stabil sehingga gejalanya dapat dianalisis. Sementara, aktivitas "ngèjhung" dalam konteks spontanitas keseharian akan sulit diprediksi secara analisis musikologis maupun momentum aktivitasnya, mengingat sifatnya yang sporadis dan spontan. Namun demikian, keberadaannya tetap menjadi bagian penting yang mendasari konstruk ekspresi kèjhungan yang mapan pada sajian formalnya. Fenomena selanjutnya, bisa kebalikannya, yaitu kèjhungan sajian formal dapat menjadi dunia pengalaman bagi ekspresi spontan dari ngèjhung masyarakat penggunanya.

Kèjhungan dalam penyajiannya telah menjadi satu kesatuan utuh dengan unsur pertunjukan lainnya, seperti unsur tarian, musik, teater, sastra, yang kesemuanya terbungkus dalam seni pertunjukan yang disebut sandur Madura. Sandur adalah teater rakyat Madura yang dianggap sebagai akronim dari "sandiwara Madura". Sandur mewadahi keberadaan kèjhungan, tandhâng (tarian) sendelan (semacam parikan atau pantun berbalas yang dialogis), serta praktik-praktik pemeranan yang memaparkan cerita keseharian. Teater ini dalam banyak hal memiliki kesamaan dengan pertunjukan ludruk jawatimuran dalam hal bentuk, struktur, maupun praktik-praktik penyajiannya. Namun belakangan ini, sandur semakin tidak utuh lagi penyajiannya sebagai bentuk teater ketika kesenian ini dimanfaatkan dalam suatu tradisi kegiatan rèmoh (arisan ala Madura). Hubungan yang intens antara kesenian sandur dan rèmoh melahirkan gejala kausalitas yang berujud indeksional, yaitu tidak ada rèmoh jika tidak ada sandur, atau sebaliknya.

Rèmoh dan sandur sedemikian digandrungi oleh komunitas blatèr, yaitu komunitas orangorang pemberani (jagoan atau jawara) Madura dari kalangan urban desa yang elitis, disegani secara sosial dan sukses secara ekonomi justru di kota-kota besar di tanah perantauannya, seperti Jawa dan Kalimantan. Bahkan, kota Surabaya yang secara geografis dekat dengan Pulau Madura menjadi basis terbesar dari eksistensi komunitas ini. Mereka mempunyai kebiasaan berkumpul secara periodik yang digalang dalam wadah arisan (rèmoh) yang begitu terorganisir rapi dan disiplin.

RèmohdalamterminologiMadurapadadasarnya merupakan kegiatan sosial berupa pelaksanaan hajat anggota masyarakat. Menurut Nilam, rèmoh mulanya merupakan kegiatan saling membantu diantara warga yang mempunyai hajat. Para warga datang dengan membawa uang, beras, gula, hewan ternak, dan lain-lain untuk disumbangkan kepada pemilik hajat. Pola solidaritas itu berkembang menjadi pola arisan yang kemudian dimeriahkan layaknya pesta. Rèmoh akhirnya menjadi kegiatan arisan "hutang-piutang" yang berskala besar, baik jumlah nominal maupun jaringan keanggotaannya di kalangan kaum blatèr (Nilam dalam Ruh Islam Dalam Budaya Bangsa, 1996: 271)

Rèmoh yang semula sekadar ajang transaksi ekonomi, kemudian menjadi ajang penguatan status sosial bagi sosok blatèr. Rèmoh menjadi sarana atas eksistensi komunitas ini yang harus dijalankan untuk menjadi blatèr yang disegani (Rozaki, 2004). Singkatnya, remoh, sandur, dan kèjhungan telah menjadi sarana aktualitas yang mengokohkan keberadaan komunitas blatèr. Tradisi rèmoh menempatkan kèjhungan dan seni pertunjukan sandur menjadi bagian dari sistim rèmoh itu sendiri.

Topik penelitian ini menekankan pada aspek pemaknaan kèjhungan dalam konteks tradisi rèmoh, serta menyoroti alasan-alasan orang blater memilih kèjhungan sebagai bagian identitasnya. Dalam hal ini, sosok Blatèr sebagai komunitas sentral yang memaknai keberadaan kèjhungan sudah seharusnya ditempatkan sebagai subjek atas objeknya (kèjhungan). Sebab, keberadaan atau keberlangsungan budaya kèjhungan telah sepenuhnya dikembangkan oleh komunitas blatèr sebagai penggunanya. Meskipun di luar fokus ini tidak dipungkiri pula bahwa masyarakat Madura umumnya mengakui keberadaan kèjhungan sebagai bagian dari habitat budaya tradisional Madura.

Kèjhungan sebagai produk dari budaya nyanyian Madura menjelaskan sekian banyak representasi yang mencerminkan spirit, karakteristik, dan pengalaman manusianya. Hal inilah yang memotivasi penelitian ini untuk mengetahui lebih dalam hubungan fakta musikal (ekspresi gaya nyanyian, cara-cara penyanyian orang Madura) dengan konteks karakteristik orang Madura melalui pemaknaan yang ditangkap oleh masyarakat penggunanya. Fokus penelitian ini adalah dunia pemaknaan masyarakat blatèr Madura terhadap kèjhungan yang memiliki kaitan 
dengan pengalaman estetik dan pengalaman budaya, serta karakteristik manusia Madura yang mendasarinya. Hal yang dicari adalah pemahaman dasar atas pertanyaan penelitian tersebut melalui penelusuran fakta empiris dan fakta ideologis terhadap aspek-aspek musikal kèjhungan maupun ketika kèjhungan dipresentasikan dalam konteks budayanya, seperti dalam tradisi rèmoh.

Aktivitas musik dalam kaitannya dengan manusia dan kebudayaannya memberi pemahaman mengenai alasan mengapa manusia bermusik, membutuhkan musik dan apa maknanya bagi mereka. John Blacking (1973) banyak membahas mengenai bagaimana manusia memperlakukan atau mengorganisir suara hingga menjadi bagian penting dalam kehidupan budayanya. Musik tidak akan dapat berkembang jika tanpa memiliki asosiasi makna diantara masyarakatnya. Oleh karenanya, musik memiliki hubungan mendalam dengan perasaan dan pengalaman masyarakatnya. Blacking menempatkan suara/musik sebagai entitas yang dapat menjelaskan suatu kebudayaan masyarakat tertentu. Thomas Turino (2008) pun juga menunjukkan bagaimana dan mengapa musik itu dibentuk; dianggap begitu penting bagi pemahaman masyarakat terhadap dirinya dan identitasnya, terhadap kelompok sosialnya, komunikasi spiritual dan emosionalnya, gerakan politik, serta aspek fundamental lainnya dalam kehidupan sosial.

Dengan kata lain, seni (dalam hal ini musik dan nyanyian) merupakan aktivitas yang berharga bagi integrasi personal dengan kelangsungan sosial dan lingkungannya. Dua pemikiran tersebut memberi dasar dan menghantarkan kepada ranah tentang bagaimana kèjhungan diciptakan, dikomunikasikan, dan dimaknai oleh masyarakat Madura sebagai pemiliknya (khususnya komunitas blatèr).

Penelitian ini pada dasarnya merupakan studi tentang "penghadiran" (representasi) nilai yang muncul pada diri kèjhungan (sebagai ekspresi estetis) yang menjadi simbol atau citra yang melegitimasikan eksistensi komunitas blatèr dalam masyarakat Madura. Dalam hal ini, teori habitus dan pembentukan "selera" (cita rasa atau taste) yang dirumuskan oleh Pierre Bourdieu dinilai relevan dalam membedah pertanyaan pokok penelitian ini. Dalam teori habitus, lingkungan (field) dilihat sebagai sebuah arena pertarungan atau ajang eksistensial individu, kelompok, komunitas (Bourdieu and Wacquant, ed., 1992: 101). Struktur lingkungan inilah yang membimbing strategi yang digunakan si "penghuni" yang berada di posisi tertentu untuk melindungi atau meningkatkan posisi mereka (Bourdieu, 1989: 14-25). Strategi kontestasi yang ditunjukkan komunitas blatèr (sebagai penghuni lingkungan) juga adalah untuk meraih posisi tertentu di masyarakat agar eksistensinya terbaca oleh publik. Contohnya, seperti bagaimana mereka menggunakan dan memaknai kèjhungan (dan sandur) dalam tradisi rèmoh.

Lingkungan adalah sejenis pasar kompetisi (kontestasi) di mana berbagai jenis modal (ekonomi, kultural, sosial, simbolik) digunakan dan disebarkan. Bourdieu membahasnya menjadi empat tipe kapital yang berangkat dari lingkungan ekonomi, di mana arti "modal ekonomi" sudah jelas berkaitan dengan uang (kapital). Lantaran kapital itulah yang memungkinkan orang untuk mengendalikan nasibnya sendiri maupun nasib orang lain (Portes and Landolt dalam American Prospect 26, 1996: 18-21). "Modal kultural" meliputi berbagai pengetahuan yang sah (pengetahuan, keyakinan, cara pandang tradisional). "Modal sosial" terdiri dari hubungan (relasi) sosial yang punya nilai diantara individu (nilai moral, etika setempat, status). "Modal simbolik" berasal dari kehormatan dan prestise seseorang. Empat jenis modal ini oleh peneliti digunakan sebagai alat untuk melihat perjuangan blatèr dalam meraih posisi. Blatèr harus menjaga eksistensinya dengan membuat simbol-simbol yang menguatkan keberadaannya.

Bourdieu memusatkan perhatiannya pada perbedaan tentang "selera" keindahan antara berbagai kelas sosial terhadap bermacam-macam objek kultural yang mengandung nilai keindahan. Selera, menurutnya, adalah juga practise (perilaku) yang antara lain memberikan pemahaman kepada seseorang mengenai posisinya di dalam tatanan sosial (Ritzer and Goodman, 2004: 527). Ada dua lingkungan (field) saling berkaitan yang terlibat dalam situasi ini, yakni hubungan kelas (sosial) dan hubungan kultur. Di sisi lain, Bourdieu juga menghubungkan selera dengan habitus. Selera dibentuk oleh habitus yang berlangsung lama, bukan dibentuk oleh opini dangkal dan retorika. Di samping itu, terdapat hubungan erat antara 
posisi sosial dan kecenderungan pelaku (agen) yang menempati posisi itu (Bourdieu, 1984: 110). Orang yang tidak setuju dengan selera dominan komunitasnya dapat luntur atau mengalah karena tekanan yang melingkupi selera simbolik milik komunitasnya. Misalnya, untuk menjadi seorang blatèr harus menerima tradisi rèmoh, kèjhungan, sandur sebagai bagian integral dari eksistensinya.

Orang mengejar kehormatan (distinction) dalam berbagai macam lingkungan kultural, memahatnya dalam produk selera-selera mereka dan diartikan kembali (interpretasi baru) setiap kali produk itu disediakan. Tujuan utama dari semuanya itu adalah seseorang atau komunitas menjadi eksis dalam ruang sosial, menjadi berbeda, menonjol, memberi kategori persepsi, terdapatnya pengklasifikasian, terdapatnya selera tertentu yang mengijinkannya untuk membuat perbedaan (Bourdieu, 1998: 9). Pernyataan ini merupakan inti dari teori Bourdieu tentang habitus melalui studi distinction-nya.

Penelitian ini, sebagaimana Bourdieu (1984) tentang Distinction, memusatkan perhatiannya tentang "selera" keindahan oleh kelompok sosial (komunitas) blatèr terhadap objek kultural yang mengandung nilai keindahan. Pertanyaan tentang makna apa yang muncul dan mengapa blatèr memilih kèjhungan sebagai simbol identitasnya? Jawabannya dapat diperoleh dari data yang dijaring lewat metode hermeneutiknya.

Gaya nyanyian atau dunia musik merupakan "bahasa" emosional yang metaforis dalam interak" sinya, sehingga membutuhkan perangkat interpretasi untuk memaknainya. Cara yang ditempuh adalah dengan mengkaitkan secara tafsiriah antara aspek formal yang kasat indera dengan aspek ideal yang tidak kasat indera. Sebab, inti dari metode interpretatif adalah menghubungkan realitas pragmatis dengan realitas ide-ide. Aspek formal yang dimaksud adalah segala sesuatu yang memberi petunjuk pada hal-hal yang dapat mendeskripsikan unsur-unsur penentu genre nyanyian/musik dan pertunjukan. Sementara, aspek ideal yang dimaksud berkisar pada wacana musikal yang meliputi 1) asumsi yang berkembang di benak para kreator [seniman], 2) referensi atau konteks-konteks yang menjadi bagian dari proses terumuskannya makna estetik, dan 3) implikasi yang dibayangkan oleh para komunikannya, khususnya komunitas blatèr.
Hal pertama yang dilakukan dalam penelitian ini adalah pengoperasian teori hermeneutik, untuk mengenali terlebih dahulu serangkaian nilai (meaning) apa yang ada dalam kèjhungan, yang pantas dijadikan sebagai modal untuk memikat selera komunitas blatèr. Hal kedua, penelitian ini berlanjut mengetahui bagian konsep habitus dan selera itu beroperasi dalam pembentukan selera komunitas blatèr terhadap kèjhungan. Metodologi ini untuk menginterpretasi atau mencari nilainilai (meaning) dalam budaya kèjhungan. Nilai itu banyak sekali dan disaring bagian mana yang pantas dijadikan modal. Nilai-nilai itu harus dikelompokkan menurut kategori modal, seperti modal ekonomi, kultural, sosial, simbolik.

Ada dua metode untuk mengoperasikan hermeneutiknya, yaitu 1) metode interpretasi data terhadap semua jenis data, seperti wawancara, pengamatan, hasil-hasil dokumentasi, dan hasil pengembangan wawasan lewat kajian pustaka dan diskusi. Dari pemahaman yang utuh itulah, kemudian menghantarkan penelitian ini kepada dasar untuk menghadirkan interpretasi-interpretasi baru dalam melihat keterkaitan komunitas blatèr memilih kèjhung. Di sinilah, teori distinction dipakai untuk mengkaji blatèr (sebagai masyarakat pengguna yang dominan) dalam rangka meraih kehormatannya melalui kèjhungan. 2) Metode riset sejarah digunakan untuk mencermati dinamika perkembangan kèjhungan melalui tiga tahapan proses: (a) memahami sudut pandang/gagasan para pelaku asli, (b) memahami makna kegiatankegiatan mereka pada hal-hal yang secara langsung berhubungan dengan dinamika kèjhungan, (c) menilai peristiwa-peristiwa tersebut berdasarkan gagasan yang berlaku pada saat pelaku sejarah itu hidup. Targetnya adalah peneliti menilai atau menginterpretasi poin (a) dan (b), dimana tahapan ini menuju pada pemaknaan atau penafsiran baru.

Berdasarkan target subjek penelitian ini, ada tiga kelompok narasumber utama yang akan dijaring, yaitu 1) komunitas blatèr, 2) pelaku kèjhungan/tandak dan musisinya, 3) budayawan atau pemerhati seni dan budaya tradisi Madura (baik dari kalangan Madura sendiri maupun dari luar Madura). Sementara, lokasi penelitian didasarkan pada pertimbangan kebasisan penyelenggaraan rèmoh dan domisili para subjek penelitian ini. Kabupaten Bangkalan (Madura Barat) 
dan Surabaya (Jawa Timur) merupakan wilayah yang paling intens menyelenggarakan rèmoh.

\section{Pembahasan}

\section{Analisis Hermeneutik Tekstual Kèjhungan}

Term "kèjhungan" dalam pengertian formal, baru dapat dikatakan memiliki makna yang baku ketika senandung seseorang tersebut diwadahi dalam kerangka gending yang telah ditentukan baik dalam bentuk kalimat lagunya, maupun alur lagunya yang mengarah pada "terminal" nada akhir tertentu. Dalam bahasa musik "terminal" itu disebut kadensa (Jawa: seleh, Madura: ghägghãr[ān]). Dengan pengertian ini, status kèjhungan secara bentuk sudah "terikat" oleh sistim karena kèjhungan berada dalam wadah kerangka gending. Berdasarkan struktur gending ini pula, kalimat-kalimat melodi pun diatur berdasarkan jumlah baris kalimat syairnya dalam setiap baitnya. Meskipun demikian, secara isi, tokang kèjhung (pengèjhung atau juru kidung) masih mempunyai keleluasaan yang cukup luas dalam mengolah cengkok-cengkok kèjhungan-nya secara individual.

Suara yang ideal untuk tokang kèjhung cenderung didasarkan pada segi pencapaian kemantapan suara lepas (los) terutama pada saat melakukan kellèk. Kellèk adalah permainan nadanada tinggi yang dilantunkan secara melismatis di antara lirik-lirik lagu yang biasanya berupa "kata hias" (kata yang sulit diartikan). Teknik ini umumnya dipergunakan pada bagian awal kalimat lagu ketika mulai dinyanyikan (angkatan awal tarikan suara).

Ciri pokok inilah yang kemudian membedakan gaya nyanyian Madura Barat yang diistilahkan kèjhungan bârâ' dengan tetangganya Madura Timur yang gaya nyanyiannya dikenal melankolis. Sementara, kesan umum terhadap kèjhungan bârâ' memiliki sifat-sifat yang kaku (gherrâ) dan kasar (blâkah), terutama jika diamati pada kontur melodi dan pengekspresiannya. Di sisi lain, kèjhungan bârầ' (Madura Barat) lebih memiliki kebebasan dalam melakukan manuver cengkok nyanyian, sehingga pembacaan kontur melodi, titinada ( $p i t c h)$, serta artikulasinya dalam pembacaan teks/lirik lagu kèjhungan relatif kurang nampak jelas. Permainan kellèk dan olah ekspresi yang kuat seringkali berakibat terhadap ketidakjelasan tersebut.

Permainan kellèk pada kèjhungan bârâ' bisa mencapai nada tinggi $3(l u)$ atau $5(m o)$ pada nada slendro. Suatu hal yang tidak lazim jika dilihat dari sudut pandang ambitus nyanyian di Jawa maupun di Madura Timur, sehingga kèjhungan bârâ’ dianggap sebagai sebuah gaya nyanyian yang "menyimpang" dari pakem orientasinya (gamelannya). Di Jawa dikenal ambang batas (ambitus) nada bagi praktik penyanyiannya hingga nada paling tinggi adalah 2 (ro), di luar itu sudah dianggap tidak lazim. Penelitian ini menemukan ambitus nada tertingginya hingga mencapai nada f.2 (dalam papan piano), atau nada 5 ( $m o$ ) dalam gamelan slendro. Capaian nada tersebut melebihi "batas maksimum" dari ambitus suara normal suara laki-laki sebagai standarnya karena yang membawakan kèjhungan bärã' tersebut umumnya laki-laki.

Ciri utama kèjhungan secara tekstual (wujud nyanyiannya) dapat dilihat dari kontur melodi, motif melodi, ornamen nyanyian (nada hias berupa pola-pola melismatis, potongan dekoratif), serta timbre, ambitus, artikulasi, dan ekspresinya.

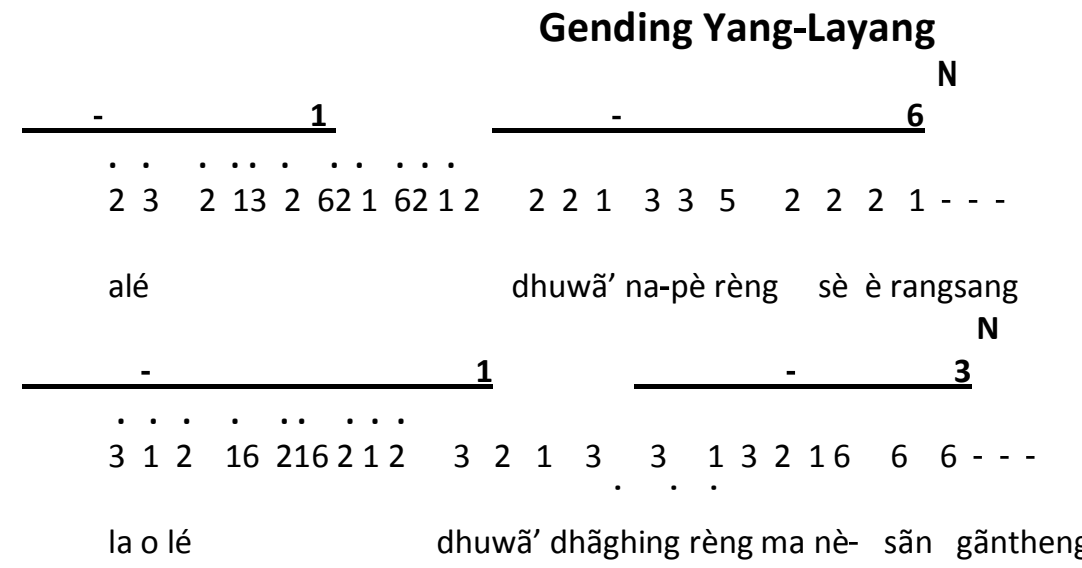




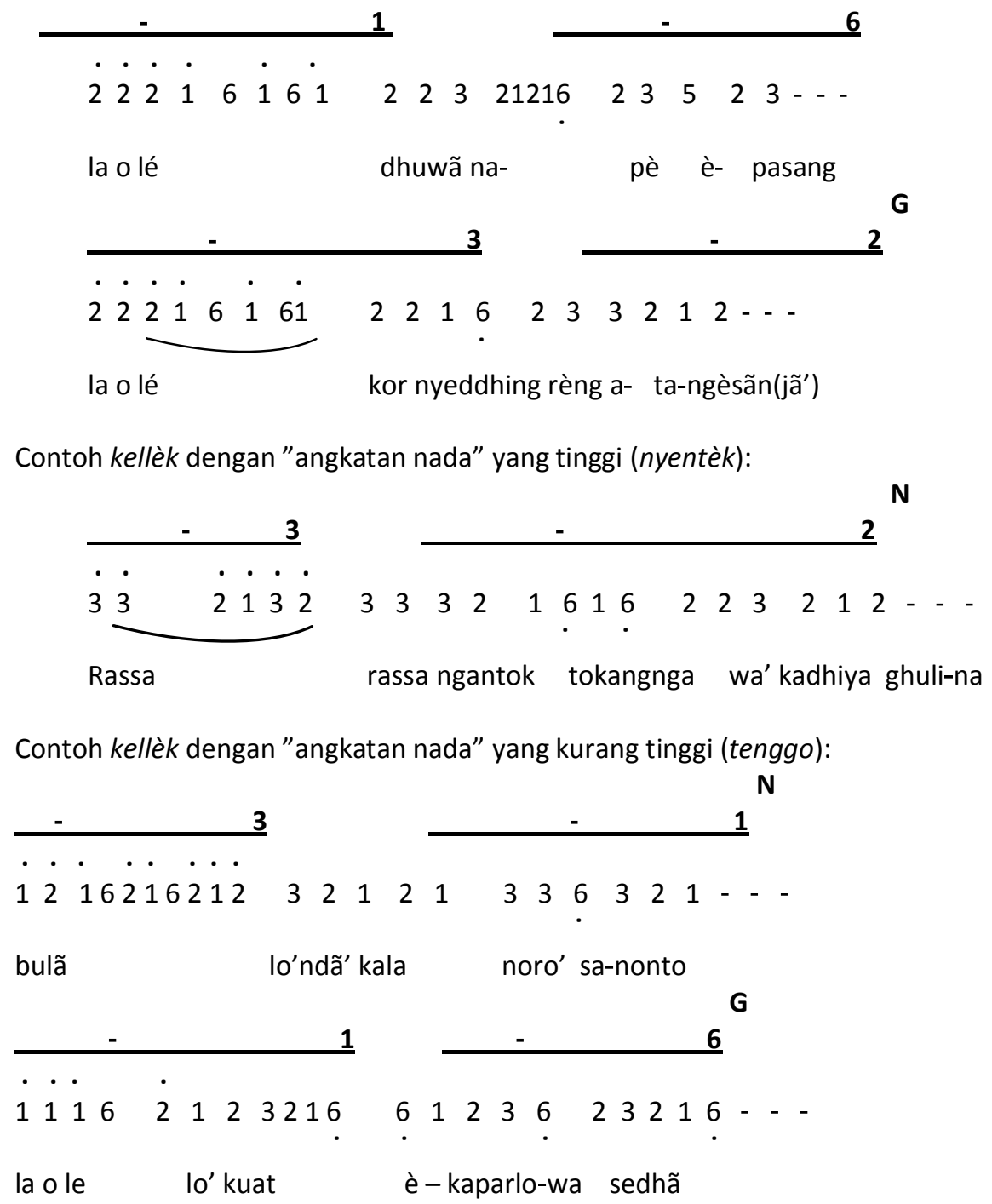

Melalui aspek ciri-ciri tekstual kèjhungan tersebut, secara mantap atau dengan kata lain lebih diketahui bahwa kellèk merupakan terminologi mementingkan pengekspresiannya daripada paling penting dalam melihat suatu gaya nyanyian acuan melodi lagunya. Hasilnya bahwa praktik Madura Barat. Dari sinilah kemudian diketahui kèjhungan umumnya dibawakan dalam cengkokkonsep-konsep ideal dan filosofis, teknik-teknik cengkok bernada tinggi, banyak pola melismatis, penyuaraan, karakter suara yang dihasilkan, serta artikulasinya terkesan dihentak-hentak sehingga posisinya dalam suatu praktik penyanyian dalam rawan terhadap ketidakjelasan titinadanya ( $p i t c h)$. gending.

Tradisi setempat mengajarkan mereka bahwa kèjhungan yang baik adalah yang mampu mempresentasikan rasa "ngaret" atau "kaghiren" baik. 


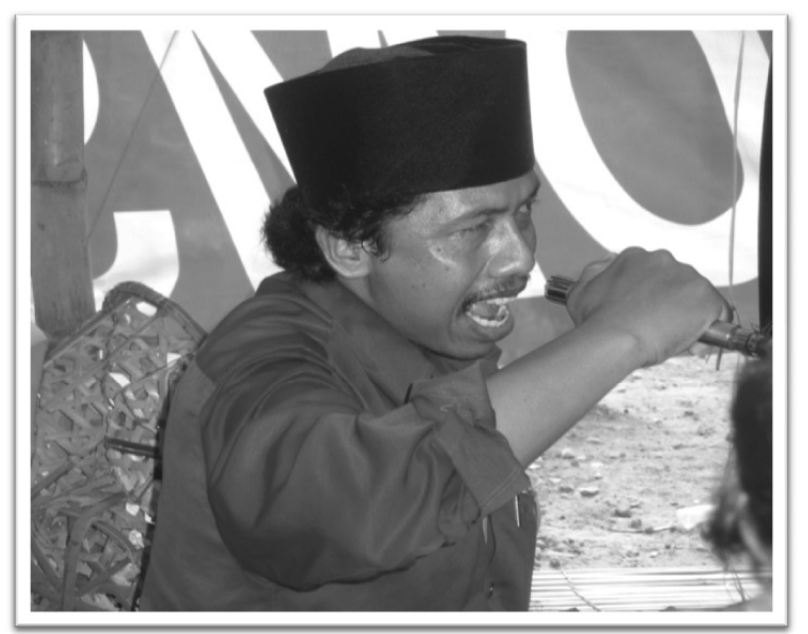

Gambar 1. Tokang kèjhung berkarakter laki-laki dituntut kemantapan greget dan jhegjheg (kokoh dan gherrâ) dengan teknik penyuaraan kerongkongan

(foto: Zulkarnain, 2010).

Keunikan kèjhungan Madura yang menonjol adalah pergerakan kontur melodi yang ekstrim. Pergerakan ini kemudian mengarahkan pada penggunaan kombinasi antara teknik penyuaraan normal dan teknik kellèk. Teknik kellèk umumnya mengandalkan pada pengendalian suara kerongkongan, sementara penyuaraan normal bertumpu pada pengendalian suara dada. Dari sisi ekspresinya, karakter kèjhungan (terutama di Madura Barat) menampilkan dominasi terhadap nada-nada tinggi yang stabil dan kuat (tennyeng), keras, kaku, bertenaga, serta memiliki greget.

Alur pergerakan melodi pokok bersifat descending (kontur menurun), namun setelah sepertiga bagian dari suatu kalimat itu terdapat semacam "patahan" (kontur yang terjal/ekstrim). Sepertiga bagian awal tersebut merupakan pusat olah kellèk yang didominasi motif melismatis. Permainan cengkok yang melengking dan bertenaga (santak) pada bagian ini seringkali mengesankan karakter musikal yang meraung sedih (mellas) tetapi dengan ekspresi menghentakhentak. Tidak mengherankan, jika akhirnya banyak orang menilai bahwa kellèk kèjhungan menjadi media atau percerminan ekspresi kejiwaan orang Madura yang muncul dari suasana hati yang kalut, kecewa, atau kurang menyenangkan.

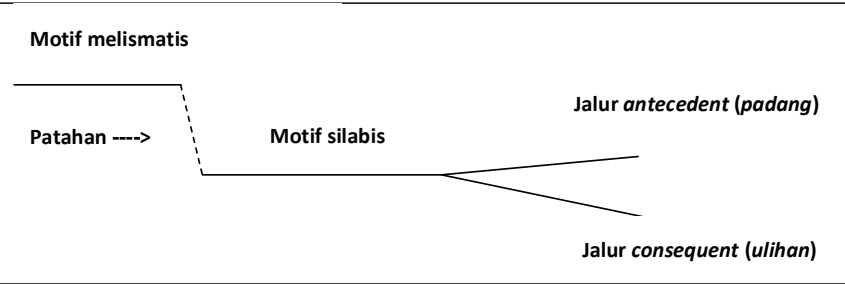

Gambar 2 : ilustrasi gamblang tentang kontur melodi kèjhungan

Ilustrasi di atas memberi gambaran bahwa pola kèjhungan teridentifikasi dalam tiga bagian dasar, yaitu bagian kellèk (disebut "angkatan"), bagian liris yang silabis, dan bagian akhir kalimat lagu (ke arah anteseden dan arah konsekuen).

Ranah teks/lirik nyanyian kurang berkembang dalam dunia kèjhungan, sebab kèjhungan lebih berpusat pada pengolahan cengkok nyanyiannya (alur melodi) daripada teks/lirik lagunya. Justru penggunaan kata-kata hias yang tidak jelas arti harafiahnya itu yang terasa lebih kuat tendensinya dalam mendukung totalitas pengekspresian kèjhungan yang ambhâ' patèh (ekspresi segenap jiwa). Do-ado, jâ'-enjâ', la-olle, e-lae dan seterusnya, merupakan kata-kata hias yang menunjukkan suasana jiwa yang mendalam, dan kata-kata arkaik seperti itu yang sering dipilih untuk dilantunkan dalam momentum kellèk tersebut. Lirik sendèlan yang umumnya pendek-pendek menjadi alasan mengapa sisipan kata-kata hias begitu kuat di Madura, selain alasan karakteristik orang Madura yang dikenal lugas dalam mengekspresikan jiwanya.

\section{Analisis Hermeneutik Kontekstual: Kèjhungan dan Sandur dalam Tradisi Rèmoh}

Citra auditif kèjhungan secara lebih luas telah dipahami sebagai indeks (tanda) oleh masyarakatnya, yaitu apabila mereka mendengar senandung kèjhungan di lingkungannya, hal itu menjadi pratanda bahwa sedang ada kegiatan rèmoh. Fenomena ini merefleksikan adanya pengidentifikasian masyarakat terhadap hubungan kèjhungan dengan dunia rèmoh menjadi satu kesatuan. Kèjhungan senantiasa menghiasi siang dan malam sebuah perhelatan rèmoh yang digelar. Kèjhungan dan tabuhan gamelan Madura tiada henti mengisi setiap bagian dari keseluruhan tahapan penyelenggaraan rèmoh, bahkan hampir 
tidak ada ruang suara kosong yang dibiarkan tanpa bunyi-bunyian gamelan dan kèjhungan. Itulah gambaran umum soundscape gelaran rèmoh.

Berikutinipenggambaran secara naratif tentang hajat rèmoh agar pembaca dapat menangkap suasana peristiwa itu lebih dekat. Gending khusus "Giroan" selalu dibunyikan manakala setiap rombongan tamu rèmoh yang jumlahnya puluhan orang itu memasuki area perhelatan rèmoh. Meskipun tamu yang hadir jumlahnya ratusan, tetapi suasana tidak berisik dan gaduh. Semua tamu duduk bersila dalam urutan yang rapi dan panjang. Hampir semua yang hadir tidak banyak bicara (apalagi bicara terlalu keras). Hal ini memberi indikasi bahwa rèmoh merupakan perhelatan formal yang sangat menjaga tatakrama dan kehormatan mereka masing-masing.

Memasuki acara pembukaan formal, sajian gending Naong Dâjầ mulai ditabuh. Gending ini selalu dimainkan apabila pertunjukan sandur akan memulai suatu acara penting (seperti halnya rèmoh). Naong Dâjâ bukan sembarang gending. Format komposisi musiknya berbeda dari yang lain, yaitu dinyanyikan secara bersama, dengan lirik-lirik arkaik (kuno, asing, dan misteri) yang dianggap sebagai simbol "doa keselamatan". Atmosfir nyanyian bersama yang melengkinglengking bersahut-sahutan mengesankan suasana mencekam dan misteri. Gending ini juga sebagai pertanda bahwa sebentar lagi tandak akan memasuki stage atau area pertunjukan yang tidak berwujud panggung.

Usai gending "keramat" itu, langsung disusul gending Yang-Layang, sebuah gending yang selalu ditampilkan sebelum acara inti dimulai. Saat itulah seorang tandak memasuki stage sambil melakukan gerakan tarian yang berpusat pada kekuatan gerakan kaki. Gerakan kakinya tampak lebih bertenaga dibanding gerak tangannya, efisien dan sederhana. Saat berikutnya dilantunkan kèjhungan gending Yang-Layang yang menuntut pengèjhungnya menampilkan kellèk demi kellèk.

Masih dalam sesi yang sama, lalu dilanjutkan dengan tarian tandhang rosak (tarian lawakan). "Tarian rusak" ini merupakan tarian komedi yang diperankan laki-laki dengan dandanan yang mengundang tawa. Tandaktandhangrosakinipaling luwes tugasnya, ia menari, ngèjhung, dan berbicara blak-blakan tanpa beban. Semua dibawakannya dengan cara yang jenaka. Justru melalui tingkah laku pelawak ini, pesan-pesan yang sebenarnya serius dapat disuarakan dengan jenaka melalui sindiran-sindiran segar. Medianya bisa lewat lirik kèjhungan maupun canda bicara yang monolog memakai bahasa campuran (bahasa Madura, Jawa, dan bahasa Indonesia). Isu yang diangkat adalah tema kepedulian sosial, etika pergaulan, ketidakadilan, dan kerukunan. Keseriusan yang disembunyikan lewat kejenakaan.

Setelah tandhang rosak, gending Yang-Layang terus dibunyikan, sementara tandak-tandak itu terus menyanyi bergantian dari balik kelir karena harus sambil berdandan dan persiapan untuk tampil pada sesi berikutnya. Andongan merupakan sesi yang diperuntukkan kepada para tamu yang ingin memberi saweran (tapelan) kepada sang tandak penari. Sang pemilik hajat adalah orang yang pertama kali maju ke arah tandak dengan langkah kaki yang tegap berwibawa untuk melakukan tarian bersama sepasang tandak dan aksi memberi tapelan. Kemudian ia menggapai mikropon yang menggantung di atas stage dan mengucapkan salam secara formal kepada seluruh tamu dengan suara lantang.

Tindakan serupa disusul oleh tokang panggil (juru panggil tamu). Ia berjalan maju untuk menari bersama dengan sepasang tandak, memberi tapelan, dan kemudian mengucapkan salam dan memberi informasi seperlunya dengan gaya bahasa, format salam, dan intonasi bicara yang nampaknya telah dibakukan. Gaya bicara senantiasa dihentak-hentakkan dengan suara lantang (walau sudah memakai mikropon), roman mukanya serius tanpa senyum pertanda menunjukkan sikap kehati-hatian yang tinggi.

Salam yang diucapkannya:

Nyara ta' langkong ka'dinto ngatoraghi salam songkemma Mat Lawi sekeluarga: Mator sakalangkong da' rèng seppo bãn tarètan sè alèngghi è lowar tèrop kantos è dalem tèrop ka aposãn. Sekalèrona tuan rumah,sareng tokang panggil, sareng tokang penyelidi', ta' lagkong nyo’ ona beccè an, sadhãjã !!

[Mohon maaf, saya di sini menghantarkan salam sungkem (hormat) dari Mat Lawi sekeluarga (pemilik hajat): Terimakasih kepada orang tua dan saudara yang duduk di luar terop hingga yang ada di dalam terop (disertai) dengan suguhan kami yang sangat sederhana ini. Apabila ada kesalahan 
penyambutan dari tuan rumah, juru panggil undangan, dan juru keamanan, (anda) dimohon berbaik hati (untuk memaafkannya), Semuanya!! ]

Kemudian, juru panggil menginformasikan jadwal rèmoh yang akan datang, dan informasi itu sekaligus sebagai undangan resmi. Dengan demikian, resmilah acara pokok rèmoh dimulai. Selanjutnya, wakil tuan rumah memanggil pertama kali tokoh setempat dimana penyelenggaraan rèmoh itu digelar, kemudian diikuti tamu-tamu senior, dan tamu peserta lainnya. Disinilah, perilaku ghendhâg (eksebisionis) dimulai dengan memasang saweran ke tubuh tandak yang melakukan tari andongan tadi. Sasaran saweran ada di belahan dada dan di atas kepala (titik itu merupakan sasaran favorit bagi penyawer). Para penyawer berbondong-bondong memasangi lembaran uang yang relatif besar nominalnya yang diselipkan di udeng sang tandak.

Acara inti rèmoh adalah acara pengumpulan uang dengan cara melakukan panggilan pada setiap tamu yang memiliki "nama panggilan" (artinya tidak semua tamu yang hadir mendapat kesempatan untuk tampil ke depan). Satu per satu tamu undangan dipanggil atas nama julukannya masing-masing dengan cara diteriakkan oleh tokang panggil, "klèbun Brakas..?" (Lurah Daerah Brakas) atau "klèbun Pasar Loak..." (Lurah [fiktif] di daerah pasar loak). Tamu yang dipanggil akan langsung menjawab: bãdă! (ada/hadir) dengan suara yang berteriak pula sambil berdiri. Seketika itu pula penabuh kendang menyahutnya dengan sentakan keras pola tepakan kendang tertentu yang mengarahkan pada permainan gending tertentu pula. Setiap panggilan selalu disertai oleh iringan "Gending Panggilan". Kemudian sang tamu bergegas berjalan dengan langkah segagah mungkin dan dengan roman muka yang serius menuju ke arah stage, dimana sepasang tandak dan sang tuan rumah sudah menunggunya. Setiap langkahnya senantiasa diiringi oleh gending yang telah dipilih oleh sang tamu sendiri sebelumnya. Gendingyang palingseringdiminta adalah gending Sabrang, Thèkthèk, Blandaran, dan Orambak.

"Panggilan" merupakan momentum sangat bermaknabagi keberadaanya sebagai seorang blatèr. Kesenangan dan rasa bangga itu tampak dari sikap dan cara berjalan yang tegap berwibawa pada saat memasuki area rèmoh sambil diiringi giroan atau gending yang telah dipilihnya. Kebanggaan dan rasa percaya diri ini juga nampak ketika menari di depan tandak dengan karakternya yang kokoh (representasi dari wibawa blatèr).

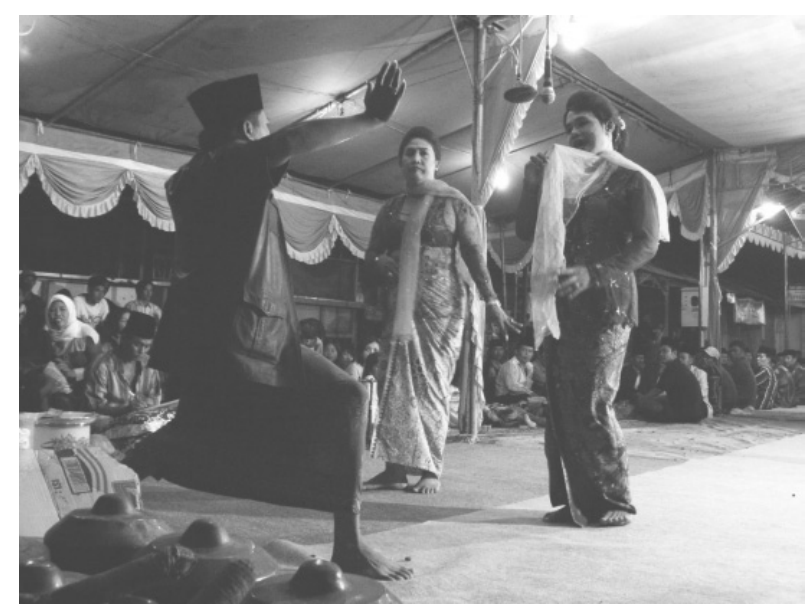

Gambar 3. Salah satu posisi gerakan menari sang tamu peserta rèmoh yang terlihat kokoh menyerupai "kuda-kuda" pencak silat (Foto: Zulkarnain, 2010)

Sang tamu panggilan sesaat menjejakkan kakinya di hadapan tandak langsung mengambil sikap menari dengan rentangan tangan yang lebar. Tidak seperti orang menari pada umumnya, sang tamu sangat membatasi gerakan tarinya, sehingga terkesan lebih banyak melakukan gerakan "diam". Sesekali ia bergerak seperti gerakan pencak silat. Gerakannya nampak kokoh dan bertenaga. Tak lama berselang, ia menghentikan tariannya lalu memberi tapelan (saweran) kepada kedua tandak. Di sinilah tugas terberat pengendang atau pemain bonang, jangan sampai ada kekeliruan dalam membunyikan gending untuk setiap tamu, serta ketepatan memberi aksen pukulan kendang dan gong dalam mengiringi gerakan tari para tamu yang mengibing. Jika tidak, kesalahan akan memicu keributan karena dapat membuat sang tamu malu dan tersinggung.

Praktik pencitraan kewibawaan dan prestisius tidak hanya berhenti di situ. Ketika pandangan sang tamu kemudian beralih ke tuan rumah yang menempatidi posisisamping stage, ia mengeluarkan segepok uang dari balik baju dan jaketnya. Dengan sikap tubuh yang masih setengah berdiri atau jongkok (tidak sampai duduk), ia menyerahkan sejumlah uang di depan tuan rumah dan juru pencatat. Sikap seperti itu tidak dianggap kurang sopan, melainkan sebuah simbol mawas diri 
yang telah diajarkan oleh pendahulunya. Setiap uang arisan yang diserahkan umumnya telah "dilebihkan" (ngompangè) dari besaran nominal yang seharusnya. Maknanya sebagai pancingan agar sang tuan rumah di waktu mendatang dapat mengembalikan uangnya sebanyak itu atau bahkan juga ngompangè yang lebih lagi.

Momentum panggilan bagi setiap tamu relatif singkat (sekitar 5 menit), namun hal ini sangat berarti bagi keberadaannya sebagai seorang blatèr dan sangat ditunggu-tunggu. Mereka akan merasa lega apabila nama julukannya telah dipanggil dan bisa abhubu (membayar arisan). Perasaan bangga dan terhormat pun diraihnya.

Selesai menunaikan kewajiban utamanya, $a b h u b u$, si tamu kembali menuju sepasang tandak dan mengambil sikap menari seperti semula, dan tidak lupa memberi tapelan lagi. Semakin banyak tamu menapel, semakin banggalah ia karena langsung disaksikan oleh para tamu yang lain. Momentum tersebut dianggap penting untuk "show of force" yang menunjukkan dirinya sebagai orang blatèr sejati.

Tabuhan gamelan, melalui aba-aba pukulan kendang, secara tiba-tiba dapat menghentikan tabuhannya manakala sang tamu melakukan gerakan menutup dengan sebuah hentakan kaki meskipun kadang tidak tepat dengan momentum seleh (kadens) pukulan gong. Kemudian sang tamu berjalan dengan sedikit membungkuk sebagai ungkapan rasa hormat kepada seluruh tamu atau forum yang telah memberikan kesempatan kepadanya.

Demikian seterusnya, hingga seluruh tamu selesai dipanggil. Acara ini memakan waktu yang sangat lama sebab tamu yang memiliki nama panggilan cukup banyak dan seluruh tamu yang hadir hingga mencapai ratusan orang (umumnya di atas 300 orang tamu). Tamu yang dianggap "sempurna" adalah tamu yang mampu melengkapi norma sebagai "Tamu Panggilan" rèmoh, yaitu punya "kewajiban" menari dengan tandak, memberi tapelan, dan menyerahkan bhubuân (uang arisan dan ompangan /uang pancingan).

\section{Kèjhungan Sebagai Representasi Simbolik dari Eksistensi Komunitas Blatèr}

Lingkungan dan ranah sosial masyarakat Madura yang khas, juga karakter tradisi rèmoh yang demikian prestisius bagi kalangan elit sosial masyarakat Madura, telah menjadi arena kontestasi nilai-nilai bagi individu maupun kelompok sosial yang hendak menempatkan status dan posisi sosialnya. Dalam hal ini, "lingkungan", sebagaimana Bourdieu, merupakan sebuah arena pertarungan yang telah menempatkan komuntas blatèr (dengan segala modal yang mereka miliki) tampil sebagai kelompok sosial yang mampu menaklukkan individu-individu maupun kelompok-kelompok sosial yang lain.

Blatèr adalah gelar sosial yang berdampak terhadap status di kalangan mereka menjadi lebih disegani, dihormati, bahkan ditakuti. Nilai ini sangat diimpikan dan semuanya dipertaruhkan untuk meraih posisi tokoh dalam dunia blatèr. Posisinya tidak hanya diperhitungkan di kalangan mereka sendiri, melainkan di mata pemerintah (birokrat) maupun kyai. Pembawaan mereka juga sangat dijaga agar nampak berwibawa dengan cara tidak banyak bicara, hati-hati dalam bertutur kata dan bertingkah laku. Di sisi lain, ia harus bersikap berani, bernyali besar, tegas dalam mengambil keputusan. Semuanya dalam rangka memperkuat citra kewibawaannya sebagai sosok blatèr.

Ada efek sosial yang diharapkan oleh para peserta rèmoh, yaitu kekuatan jaringan elit desa. Konflik sosial akan lebih mudah diatasi apabila mereka berada dalam jaringan orèng blatèr. Individu yang berada dalam jaringan ini sangat hati-hati dalam mengambil keputusan dan saling menjaga etika, saling menghormati, terutama bagi sesama blatèr. Oleh karena itu peranan para tokoh blatèr menjadi kendali bagi anak buahnya. Demikian pula, anak buah yang juga peserta rèmoh juga memiliki peranan penting di tingkat akar rumput. Perasaan ditokohkan barangkali jauh lebih penting artinya bagi mereka dari sekadar mencari kekayaan. Sebab, rèmoh bukan tempat mencari kekayaan, melainkan strategi membangun kewibawaan, kekuasaan, atau pengaruh ketokohan di masyarakat, serta jaringan antar blatèr sendiri.

Komunitas rèmoh merupakan komunitas yang digandrungi oleh kalangan para "jawara” kaum blatèr, maka tidak mengherankan jika suasana rèmoh sangat ketat aturan karena dianggap rawan konflik. Peraturan rèmoh sangat dijunjung tinggi, di antara mereka harus bisa saling menjaga diri dan dalam keadaan "siaga" jika nantinya terjadi hal yang tidak diinginkan. Situasi yang penuh 
kehati-hatian tersebut, sering membuat suasana mencekam. Kehadiran unsur kesenian pun terasa kurang menonjol sebagai hiburan semata, melainkan diposisikan sebagai aspek pengabsah secara kultural dalam penyelenggaraan rèmoh.

Rèmoh memang menjadi habitat atas eksisnya pertunjukan sandur dan kèjhungan. Sebaliknya pula, rèmoh tanpa sandur tidak akan pernah dapat dilakukan acara panggilan yang khas kepada para peserta rèmoh yang sesungguhnya menjadi inti dari kegiatan ini. Kèjhungan dan sandur adalah dimensi estetik yang melekat dalam eksistensi rèmoh Madura.

Kegiatan rèmoh, kèjhungan, sandur, serta relasi sosial yang solid dan "rapi" dalam komunitas blatèr merangkai keseluruhan modal (yang menurut teori distingsi Bourdieu) akan menentukan masyarakat atau komunitasnya untuk menjatuhkan pilihan selera (taste) atau cita rasa budayanya pada produk estetika tertentu. Modal-modal tersebut adalah 1) modal ekonomi, 2) modal sosial, 3) modal kultural, dan 4) modal simbolik. Hal pertama yang sudah dijelaskan pada bagian aktivitas rèmoh maupun komunitas blatèr adalah modal ekonomi. Rèmoh dan blatèr merupakan entitas ekonomi yang melahirkan kekuatan kapital dan terorganisir rapi. Rèmoh merupakan kegiatan arisan yang bisa menggelembungkan kekuatan ekonomi kapital dan jaringan bisnis diantara para pesertanya (komunitas blatèr), dengan sendirinya akan menjadi kekuatan pula dalam menentukan taste bagi komunitasnya.

Adapun modal sosial dan kultural yang dimiliki oleh kalangan blatèr sesungguhnya saling berkaitan dalam hal pembentukan selera, yakni hubungan kelas (sosial) dan hubungan kultur. Komunitas blatèr yang memiliki jaringan "organisasi" yang rapi, hirarkis, dan solid dengan sendirinya merupakan modal sosial yang amat canggih untuk menentukan sikap, perilaku, gaya/ performa, hingga cita rasa atau selera (seni). Sementara, nilai-nilai kultural yang ada dalam rèmoh dan kèjhungan telah eksis secara bentuk, dan kokoh dalam hal simbol dan muatan citra kemaduraannya. Itu semua adalah magnitude yang mapan (modal kultural yang terbelikan) untuk memikat komunitas yang gemar mempercantik citra dirinya seperti kalangan blatèr tersebut. Pencitraan diri yang disandangnya itu sangat diwarnai oleh pengetahuan, keyakinan, dan cara pandang yang mereka miliki sebelumnya.

Modal simbolik yang berasal dari kehormatan dan prestise seseorang dengan sendirinya telah termaktub pada saat sebuah komunitas menjatuhkan pilihan selera untuk selanjutnya mengembangkan nilai-nilai yang ada pada produk selera tersebut agar menjadi sesuatu yang secara simbolik maupun praktis mampu memunculkan prestise para pelakunya. Dalam kaitan ini, kèjhunganyang mampumenghadirkan keseluruhan nilai-nilai simbolik dan citra kemaduraan adalah pilihan utama dalam menancapkan selera estetis musikalnya.

Selera keindahan berbagai kelas sosial, menurut Bourdieu, cenderung berbeda-beda secara signifikan. "Selera" ternyata adalah juga praktik (perilaku) yang memberikan seseorang individu maupun orang lain suatu pemahaman mengenai posisinya di dalam tatanan sosial (Ritzer and Goodman, 2003: 527). Melalui penerapan habitus dan selera, orang menggolong-golongkan objek dan sekaligus mereka berada dalam proses penggolong-golongan diri mereka sendiri. Dalam hal ini, komunitas blatèr yang telah, sedang, dan akan selalu memperkokoh citra kemaduraannya, dengan bangga menjatuhkan selera estetisnya pada kèjhungan dan sandur. Pemilihan selera ini tentu saja bukan dibentuk oleh opini dangkal dan retorika, melainkan dibentuk oleh habitus yang berlangsung lama dan selanjutnya diwujudkan melalui kekuatan modal-modal yang dimilikinya tadi.

Representasi posisi sosial blatèr bahwa orang akan mengejar kehormatan (distinction) dalam berbagai lingkungan kultural. Apapun yang dikomsumsi, disenangi, diapresiasi, bahkan yang dialami, merupakan bentuk relasional antara subyek [orang] dan obyek [lingkungan] yang saling berintegrasi dalam kesatuan praktik sosial yang mencerminkan sifat-sifat habitus, modal dan ranah yang dikuasai. Dengan kata lain, hubungan itu secara obyektif terpahatkan dalam produk yang menjadi selera mereka dan diartikan kembali (interpretasi baru) setiap kali produk itu disediakan. Begitulah Bourdieu dalam menjelaskan konsep distingsi seseorang ataupun kelompok sosial dalam meraih kehormatan (Bourdieu, 1998: 9). Secara skematis, konsep Bourdieu dapat dijabarkan pada subjek blatèr sebagai berikut: 


\section{Komunitas Blatèr}

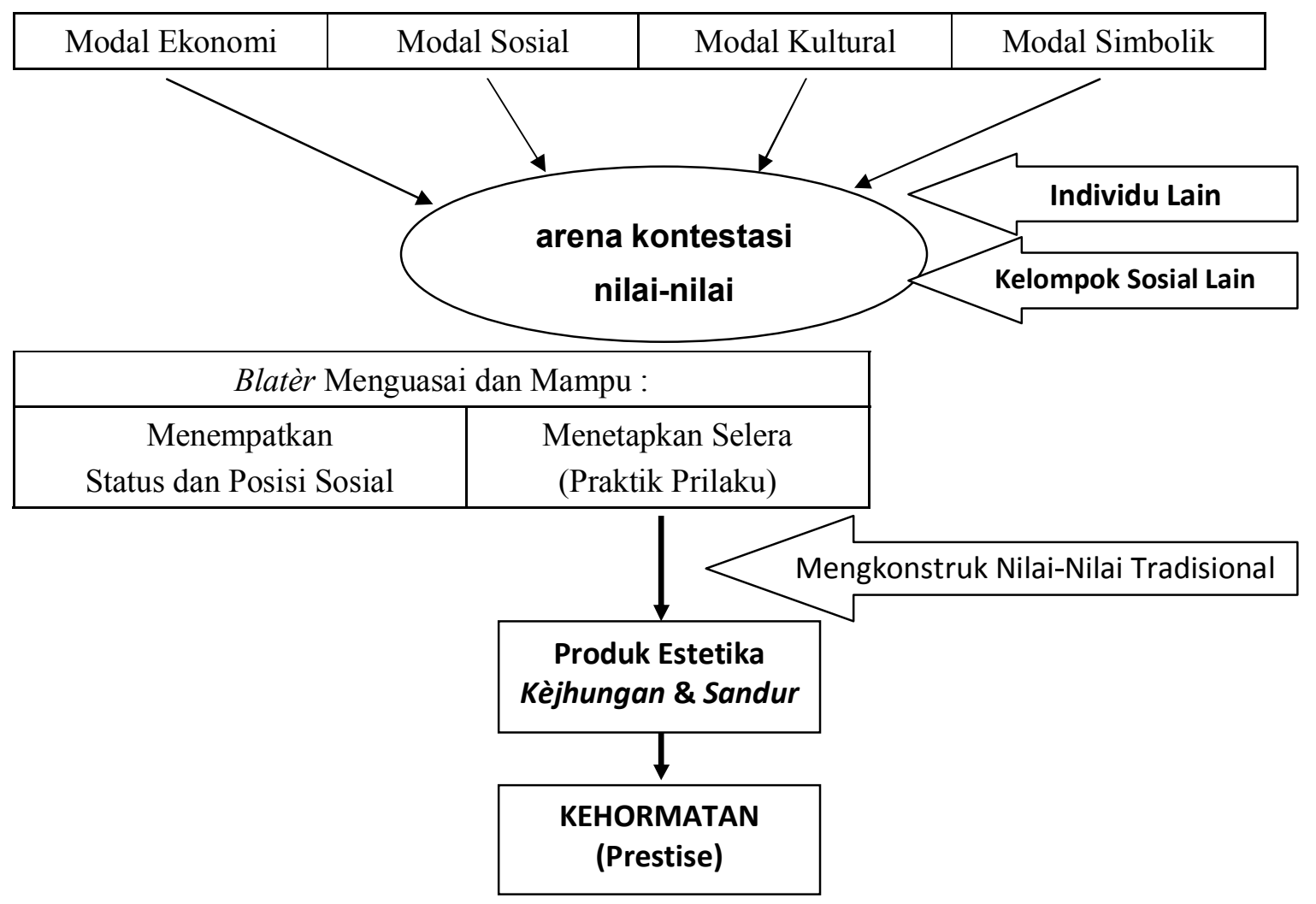

Komunitas blatèr telah membangun posisi sosialnya secara eksis, kokoh, dan disegani masyarakat Madura melalui penguatan produk kesenian yang paling digemari, yaitu kèjhungan sebagai obyeknya. Bagaimana kèjhungan sampai bisa diapresiasi sedemikian rupa hingga mengeliminasi ekspresi-ekspresi estetis lainnya, tentu hal ini tidak lepas dari nilai-nilai obyektif dalam kèjhungan yang mampu menghadirkan simbol dan bahkan ikon untuk merepresentasikan eksistensi komunitas blatèr.

Kejjhungan melalui paparan hermeneutik tekstual di atas, menegaskan karakternya sebagai gaya nyanyian yang menuntut performa yang nyaring (santak), tinggi (nyenthèk), kuat/ bertenaga, stabil (tennyeng), kaku/kasar (gherrâ), lugas, memiliki greget dan menghentak. Namun, kèjhungan sekaligus memaparkan karakter sedih (mellas), keluh kesah atau rintihan dalam bingkai melodi nyanyian yang penuh hayat (lèkalèllèan). Paparan hermeneutik tekstual ini nampaknya memiliki hubungan dengan kesan yang ditangkap orang blatèr tentang kèjhungan yang lebih dimaknai sebagai "senandung jiwa yang meronta". Setidaknya, ekspresi kèjhungan tersebut telah dihimpun oleh komunitas blatèr dan dianggap mampu menghadirkan nilai-nilai kemaduraan yang relevan dengan karakter mereka yang "keras" dan pengalaman sejarah sosial yang getir dari masyarakat Madura secara umum (lihat kuntowijoyo [2002], Rozaki [2004]).

Praktik penyanyian kèjhungan (dengan muatan nilai yang ada tersebut) yang disuarakan seorang tandak itu terapresiasikan secara langsung kepada komunitas blatèr. Melalui bingkai pertunjukan sandur dan rèmoh, praktik kèjhungan juga semakin mudah (kuat) diusung menjadi elemen penting bagi pencitraan atas keberadaan kaum blatèr. Nilai kejiwaan inilah yang kemudian disukai dan diidentifikasikan dengan personalitas seorang blatèr. Demikian pentingnya kèjhungan bagi komunitas ini membuat kehadirannya secara 
kontekstual dalam rèmoh nyaris tak tergantikan oleh musik atau kesenian lain. Setidaknya, kèjhungan mampu menjadi ruang katarsis tersebut bagi komunitas blatèr.

Kèjhungan menjadi begitu bermakna bagi kaum blatèr dan selanjutnya dipilih sebagai representasi atas eksistensinya di tengah-tengah masyarakat Madura. Orèng blatèr yang hidup sukses di kota besar seperti Surabaya dan Jakarta pun tidak meninggalkan kebiasaannya terhadap sandur dan kèjhungan-nya karena jenis kesenian inilah yang dinilai mampu menjaga intensitas keblatèran mereka. Di mobil-mobil dan rumahrumah mereka masih tersimpan berbagai koleksi album rekaman sandur-kèjhungan, diperdengarkan pada saat-saat tertentu, menandakan komunitas ini masih cukup kuat untuk mempertahankan simbol-simbol eksistensi blatèr yang telah banyak memberi andil dalam kompleksitas hidup mereka di kota besar.

\section{Penutup}

Kèjhungan dibangun dari modal kultural seperti karakter manusia Madura yang "keras" dan pengalaman historis dari sosio kultural Madura. Ketika kèjhungan telah menjadi sebuah gaya nyanyian yang "mapan", maka pertimbangan terhadap mengedepankan karakter kèjhungan yang nyaring (santak), tinggi (nyenthèk), kuat dan stabil (tennyeng), kaku, kasar (gherrâ), ada greget, namun sekaligus berkarakter sedih (mellas) dan berkeluh kesah. Kellèk hadir sebagai refleksi dari jeritan kesedihan dari nilai kejiwaan dan karakteristik orang Madura secara holistik. Demikianlah cara orang Madura dalam mengungkapkan ekspresi jiwanya melalui perilaku musikalnya.

Kèjhungan telah menjadi obyek konsumsi yang canggih bagi kaum blatèr dalam rangka meraih kehormatannya. Bahkan dalam ranah yang lebih luas, kèjhungan sebagai budaya musik telah diposisikan pada orientasi kesadaran yang penting dalam pencarian identitas kemaduraan mereka. Kèjhungan juga dianggap mampu menempatkan dirinya sebagai bagian yang penting dalam keseluruhan budaya nyanyian orang Madura. Kejhungan hadir sebagai sebuah gaya (style) yang "genuine" dari cara bernyanyi orang Madura. Di sinilah, kita sesungguhnya telah diperlihatkan sebuah kontinuitas dan transformasi budaya yang terjadi di masyarakat Madura.
Sebagaimana ditunjukkan oleh Bourdieu, keterkaitan kekuasaan kaum blatèr dengan kèjhungan sebagai pilihan practice (perilaku) estetiknya tersebut, tidak terlepas dari kesesuaian karakter antar keduanya dan proses pencitraan kejhungan sebagai satu bentuk representasi eksistensi komunitas blatèr. Pada proses pencitraan inilah kekuasaan itu beroperasi. Dengan kekuasaan yang dimilikinya, kaum blatèr telah mampu mengonstruksi nilai-nilai tradisional kèjhungan menjadi simbol-simbol yang cemerlang dalam kerangka mengokohkan eksistensi kehadirannya di tengah masyarakat.

\section{Kepustakaan}

Blacking, John. 1974. How Musical is Man? Washington: University of Washington Press.

Bourdieu, Pierre. 1984. Distinction: A Social Critique of the Judgment of Taste. Cambridge, Massachusetts: Harvard University Press. 1989. "Social Space and Symbolic Power" in Sociology Theory 7.

$$
\text { 1998. Practical Reason. }
$$

Stanford California: Stanford University Press.

Bouvier, Helene. 2002. Lebur! Seni Musik dan Pertunjukan dalam Masyarakat Madura. Jakarta: Yayasan Obor.

Bruner, Edward M., dan Victor W. Turner. 1986. The Anthropology of Experience. Urbana and Chicago: University of Illinois Press.

Buys J.S \& A. Brandts. 1928. "De Toonkunst Bij De Madoereezen" dalam Jawa VIII. Weltevreden.

De Jonge, Huub. (ed.). 1989. Agama, Kebudayaan, dan Ekonomi. Jakarta: Rajawali Press.

Kuntowijoyo. 2002. Perubahan Sosial dalam Madura 1850-1940. Yogyakarta: Mata Bangsa, bekerja sama dengan Yayasan Adikarya IKAPI dan The Ford Foundation.

Nilam, H. Muhammad, 1996. "Perilaku Bisnis Orang Madura Kontemporer" dalam Ruh Islam Dalam Budaya Bangsa, (Aneka Budaya di Jawa) (Jakarta: Yayasan Festival Istiqlal,

Portes, Alejandro and Patrica Landolt, "The Downside of Social Capital", American Prospect 26., 1996, 
Rozaki, Abdur. 2004. Menabur Kharisma Wacquant (eds). 1992. An Invitation to Reflexive Menuai Kuasa, Kiprah Kiai dan Blater sebagai Sociology. Chicago: University of Chicago Press.

Rezim Kembar di Madura. Yogyakarta: Pustaka Turino, Thomas. 2008. Music as Social Life: Marwa.

The Politic of Participation. Chicago and London:

Ritzer, George \& Douglas J. Goodman, 2004. The University of Chicago Press.

Teori Sosiologi Modern. Jakarta: Kencana.

"The Purpose of Reflexive Sociology (The Chicago Workshop)" in P. Bourdieu and L.J.O. 